\title{
OPTIMALISASI KONDUKTIVITAS IONIK ELEKTROLIT POLIMER BERBASIS KOMPOSIT KITOSAN-ZIRKONIA/LITIUM PERKLORAT DENGAN PENAMBAHAN GLISEROL
}

\author{
Evi Yulianti ${ }^{1}$, Dayu Luthfiah $^{2}$, dan Sudaryanto ${ }^{1}$ \\ ${ }^{1}$ Pusat Sains dan Teknologi Bahan Maju (PSTBM)-BATAN \\ Kawasan Puspiptek, Serpong, Tangerang Selatan 15314 \\ ${ }^{2}$ Departemen Fisika, FMIPA, UIN Syarif Hidayatullah \\ JI. Ir. Haji Juanda No. 95, Ciputat, Tangerang Selatan 15412 \\ E-mail : yulianti@batan.go.id
}

Received: 1 Februari 2017; revised: 13 Maret 2017; accepted: 21 Maret 2017

\begin{abstract}
ABSTRAK
OPTIMALISASI KONDUKTIVITAS IONIK ELEKTROLIT POLIMER BERBASIS KOMPOSIT KITOSANZIRKONIA/LITIUM PERKLORAT DENGAN PENAMBAHAN GLISEROL. Untuk meningkatkan nilai konduktivitas ionik elektrolit polimer, telah dilakukan modifikasi terhadap sistem komposit kitosan- $\mathrm{ZrO}_{2} / \mathrm{LiClO}$ dengan menambahkan gliserol sebagai plasticizer. Pembuatan lembaran elektrolit polimer dilakukan dengan metode casting, setelah seluruh komponen dicampur secara bertahap dan diaduk dengan pengaduk magnet. Penambahan plasticizer dilakukan dengan berbagai komposisi yaitu antara 0\% (g/g) sampai dengan $80 \%$ (b/b). Elektrolit polimer kemudian dikarakterisasi meliputi struktur mikro dengan difraksi sinar-X (XRD), sifat mekanik dengan uji tarik menggunakan UTM, spektrometer impedansi (LCR-meter) dan pengukuran jumlah transferensi ion. Hasil karakterisasi dengan $X R D$ dan uji sifat mekanik menunjukkan bahwa elektrolit polimer menjadi semakin amorf dan elastis dengan penambahan plasticizer. Penambahan plasticizer yang optimal adalah sebanyak $60 \%$ (b/b) dimana pada komposisi tersebut masing-masing diperoleh bilangan transferensi ion tertinggi 0,85 dengan nilai konduktivitas ionik $3,52 \times 10^{-4} \mathrm{~S} / \mathrm{cm}$.
\end{abstract}

Kata kunci : Kitosan, $\mathrm{ZrO}_{2}$, Gliserol, Bilangan transferensi ion

\section{ABSTRACT}

OPTIMALIZATION OF IONIC CONDUCTIVITY OF POLYMER ELECTROLYTE BASED ON CHITOSANZIRKONIA/LITHIUM PERCHLORATE COMPOSITES BY GLYCEROL ADDITION. In order to increase the ionic conductivity of polymer electrolyte, modification of chitosan-ZrO2/LiClO ${ }_{4}$ composites has been done by addition of glycerol as a plasticizer. Polymer electrolyte films were prepared through a casting method. Before the casting, all components were mixed gradually under a magnetic stirrer. Plasticizer additions were varied in different composition range of $0 \%(\mathrm{w} / \mathrm{w})$ until $80 \%(\mathrm{w} / \mathrm{w})$. Characterization of the solid electrolyte film was conducted using $X$-ray diffractometer (XRD) for the crystal structure, mechanical properties by Universal Testing Machine (UTM), impedance spectrometer (LCR-meters) for conductivity, and determination of ion transference number. X-ray diffraction (XRD) data and mechanical testing show that polymer electrolyte became more amorphous and elastic with plasticizer addition. The optimum composition of plasticizer was at $60 \% \mathrm{w} / \mathrm{w}$, which was the highest ionic transference number of 0.85 and ionic conductivity of $3.52 \times 10^{-4} \mathrm{~S} / \mathrm{cm}$.

Key words : Chitosan, $\mathrm{ZrO}_{2}$, Glycerol, Ionic transference number

\section{PENDAHULUAN}

Bahan elektrolit polimer padat (Solid Polymer Electrolyte/SPE) pertama kali ditemukan oleh Fenton dan Wright pada tahun 1973 yang meneliti konduktivitas ionik pada polimer polietilen oksida yang ditambah garam alkali. Penelitian tentang bahan ini banyak menarik perhatian karena prospek penggunaannya yang sangat potensial seperti pada baterai sekunder litium, sensor, solar cell, fuel cell dan bahan elektrokromik. Pada sistem baterai litium, bahan elektrolit polimer padat berfungsi sebagai penghantar ion litium antar elektroda sekaligus bertindak sebagai separator. Bahan elektrolit polimer memiliki keunggulan antara lain mudah kontak dengan komponen elektroda, mudah difabrikasi dalam bentuk film tipis dan mempunyai sifat listrik, optik dan mekanik yang baik. Selain itu bahan ini tidak bersifat reaktif 
terhadap litium sehingga meningkatkan keamanan pada saat penggunaannya. Elektrolit polimer padat (SPE) biasanya dibuat dengan menambahkan bahan anorganik seperti garam litium ke dalam matriks polimer. Bahan elektrolit polimer yang banyak diteliti adalah polietilen oksida, akan tetapi karena derajat kristalinitas bahan ini tinggi menghalangi penggunaannya pada baterai karena hanya dapat digunakan pada temperatur di atas temperatur lelehnya sehingga perlu dicari bahan polimer lainnya (Fonseca dan Neves 2006; Stephan dan Nahm 2006; Rahman et al. 2011).

Bahan polimer lain juga telah banyak diteliti untuk dikembangkan menjadi bahan elektrolit padat, antara lain polimetilmetakrilat $(P M M A)$, polivinil klorida $(P V C)$ dan polivinilidin fluorida (PVDF) (Stephan and Nahm 2006; Noor et al. 2011; Rahman et al. 2011; Kuo et al. 2013; Deraman, Mohamed, and Subban 2013). Semua ini merupakan polimer sintetis yang susah terdegradasi di alam dan bersifat tidak ramah lingkungan. Oleh sebab itu perlu dicari jenis polimer lain yang biodegradable serta ramah lingkungan untuk dikembangkan menjadi bahan SPE. Kitosan merupakan salah satu kandidat yang sesuai sebagai bahan elektrolit padat karena merupakan polimer alam yang bersifat biodegradable. Selain itu kitosan harganya relatif murah karena ketersediaannya di alam cukup melimpah, kelarutannya tinggi dan mudah dibuat menjadi film. Pada saat ini kitosan banyak digunakan sebagai bahan pengemas makanan, serat untuk bahan diet dan aplikasi biomedis untuk penghantar obat (drug delivery)(Tripathi, Mehrotra, dan Dutta 2008; Schnürch and Dünnhaupt 2012; Anitha et al. 2014).

Kitosan sendiri bersifat isolator. Agar bisa dipakai sebagai bahan elektrolit, kitosan harus dimodifikasi sehingga konduktivitasnya meningkat. Salah satu cara untuk meningkatkan konduktivitas ionik kitosan disamping penambahan garam-garam adalah dengan menambahkan filler oksida berukuran nano seperti $\mathrm{TiO}_{2}$, monmorillonit $\mathrm{SiO}_{2}, \mathrm{Al}_{2} \mathrm{O}_{3}$ dan $\mathrm{ZrO}_{2}$ (Navaratnam, Ramesh, and Basirun 2011; Winie et al. 2014; Yulianti et al. 2013; Aziz and Abidin 2014). Selain itu teknik implantasi ion juga bisa dikembangkan untuk meningkatkan konduktivitas ionik kitosan (Yulianti, Karo, dan Susita 2012). Akan tetapi konduktivitas yang diperoleh relatif masih rendah sekitar $\sim 10^{-5} \mathrm{~S} / \mathrm{cm}$. Oleh sebab itu penambahan plasticizer seperti etilen karbonat, propilen karbonat, etilen glikol, gliserol diharapkan bisa meningkatkan konduktivitas ionik hingga 2 orde (Harun et al. 2011; Noor et al. 2011). Plasticizer merupakan bahan organik dengan berat molekul rendah dan mempunyai nilai konstanta dielektrik tinggi. Penambahan plasticizer ke dalam matriks polimer akan meningkatkan fasa amorf polimer serta dapat meningkatkan fleksibilitas dan dissosiasi garam menjadi pasangan kation dan anion bebas. Dari beberapa penelitian sebelumnya menunjukkan penambahan asam oleat ke dalam film elektrolit kitosan-litium asetat bisa meningkatkan konduktivitas dari orde $10^{-7} \mathrm{~S} / \mathrm{cm}$ menjadi $5.5 \times 10^{-6} \mathrm{~S} / \mathrm{cm}$. Pada penelitian yang dilakukan Buraidah et al. (2009), konduktivitas kitosan- $\mathrm{NH}_{4} \mathrm{I}$ juga meningkat dengan penambahan etilen karbonat, begitu juga penambahan plasticizer pada sistem kitosan- $\mathrm{NH}_{4} \mathrm{SCN}$ bisa meningkatkan konduktivitas kitosan hingga $1,51 \times 10^{-3} \mathrm{~S} / \mathrm{cm}$ (Yahya dan Arof 2003; Buraidah et al. 2009; Shukur et al. 2013).

Berdasarkan penjelasan di atas pada penelitian ini akan dipelajari pengaruh penambahan gliserol sebagai plasticizer pada sistem elektrolit polimer berbasis komposit kitosan- $\mathrm{ZrO}_{2}$ yang telah ditambah garam $\mathrm{LiClO}_{4}$ (Yulianti, Ginting, and Sudaryanto 2015; Sudaryanto, Yulianti, and Patimatuzzohrah 2016). Penambahan gliserol diharapkan akan meningkatkan konduktivitas dan jumlah transferensi ion dari film elektrolit berbasis kitosan sehingga bisa diaplikasikan dalam sistem baterai.

\section{BAHAN DAN METODE}

\section{Bahan}

Penelitian ini menggunakan kitosan yang diisolasi dari kulit udang di laboratorium Pusat Aplikasi Isotop dan Radiasi (PAIR)-BATAN, disamping itu digunakan asam asetat kemurnian $100 \%$ (Merck) sebagai pelarut, zirkonia $\left(\mathrm{ZrO}_{2}\right)$ sebagai filler, garam lithium perklorat kemurnian $95 \%+\left(\mathrm{LiClO}_{4}\right)$ (Aldrich) sebagai sumber ion $\mathrm{Li}$ dan gliserol kemurnian $98 \%$ (Merck) sebagai plasticizer serta aquades.

\section{Metode}

Film komposit kitosan $\mathrm{ZrO}_{2}$ dibuat dengan metode casting. Serbuk $\mathrm{ZrO}_{2}$ dengan komposisi $4 \%(\mathrm{~b} / \mathrm{b})$ ditambahkan ke dalam larutan asam asetat $1 \%$ dan diaduk selama \pm 30 menit agar terdispersi dengan baik (Sudaryanto, Yulianti, dan Patimatuzzohrah 2016). Kemudian ditambahkan serbuk kitosan secara bertahap hingga diperoleh larutan kitosan 4\%. Setelah kitosan larut sempurna, selanjutnya ditambahkan garam litium perklorat sebanyak $40 \%$ (b/b) dilanjutkan dengan pengadukan hingga garam larut sempurna. Ke dalam campuran kemudian ditambahkan gliserol variasi konsentrasi $0 \%$ (b/b) sampai dengan $80 \%(\mathrm{~b} / \mathrm{b})$ dan diaduk hingga homogen. Kemudian Iarutan dituang ke dalam cawan petri dan dimasukkan ke dalam oven pengering untuk dikeringkan secara perlahan-lahan pada temperatur $45^{\circ} \mathrm{C}$ 
selama 5 hari sampai terbentuk film komposit elektrolit polimer.

\section{Karakterisasi Sampel}

Film komposit elektrolit polimer selanjutnya dikarakterisasi meliputi pola difraksi sinar-X yang diamati dengan $X$-ray Diffraction (XRD) Empyrean PANalytical (45 kV, $40 \mathrm{~mA})$ menggunakan radiasi $\mathrm{Cu} \mathrm{K} \alpha(\lambda=0.15406 \mathrm{~nm}$, $0.02 \mathrm{deg} / \mathrm{step})$ dipindai pada sudut $2 \theta 5^{\circ}-60^{\circ}$. Konduktivitas ionik serta sifat listrik lainnya diukur menggunakan LCR Hi-tester HIOKI 3532-50. Uji sifat mekanik dilakukan dengan peralatan Universal Testing Machine (UTM) yang prosedur pengujiannya mengacu pada ASTM tipe D-1822-L. Bilangan transferensi diukur dengan teknik polarisasi menggunakan tegangan $\sim 1,5 \mathrm{~V}$ yang diberikan terhadap sampel yang dihubungkan dengan multimeter dan switch. Teknik pengukuran ini mengacu pada metode pengukuran yang dilakukan oleh Morni dan Arof (1999).

\section{HASIL DAN PEMBAHASAN}

Studi pengaruh penambahan gliserol terhadap struktur elektrolit polimer berbasis komposit kitosan- $\mathrm{ZrO}_{2}$ dilakukan dengan melihat pola difraksi yang terbentuk. Berdasarkan hasil pengamatan $X R D$ diperoleh pola difraksi kitosan- $\mathrm{ZrO}_{2}-\mathrm{LiClO}_{4}$ seperti pada Gambar 1. Penambahan gliserol kedalam kitosan- $\mathrm{ZrO}_{2}$ $\mathrm{LiClO}_{4}$ mempengaruhi kristalinitas sampel. Kitosan- $\mathrm{ZrO}_{2}-\mathrm{LiClO}_{4}$ tanpa penambahan gliserol memiliki puncak yang agak tajam pada sudut $2 \theta$ $11,45^{\circ}$ dan $18,53^{\circ}$ (tanda bintang) (Gambar 1.2) yang menunjukkan matriks polimer bersifat semikristalin (Yulianti, Karo, dan Susita 2012).

Penambahan gliserol sebagai plasticizer mengubah struktur dari sistem komposit kitosan.
Puncak difraksi kitosan pada sudut $2 \theta 11,45^{\circ}$ dan $18,53^{\circ}$ tidak lagi terlihat setelah penambahan gliserol. Pelebaran puncak difraksi semakin melebar sebanding dengan kenaikan konsentrasi gliserol. Puncak yang paling lebar dimiliki oleh sampel dengan kandungan gliserol $80 \%$ seperti pada Gambar 1.5) artinya pada konsentrasi tersebut sampel berada dalam keadaan yang paling amorf. Di dalam matriks polimer kitosan garam $\mathrm{LiClO}_{4}$ juga terlarut sempurna, karena dari pola difraksi yang dihasilkan sudah tidak muncul puncak difraksi garam tersebut.

Perubahan sifat mekanis film komposit kitosan $\mathrm{ZrO}_{2}$ akibat penambahan gliserol dapat diketahui dengan mengukur kekuatan tarik dan perpanjangan putusnya seperti terlihat pada Gambar 2. Kekuatan tarik adalah tegangan regangan maksimum sampel sebelum putus. Pada film yang ditambahkan gliserol, nilai kuat tarik menurun seiring dengan peningkatan konsentrasi gliserol. Dari kurva (a) didapatkan informasi bahwa peningkatan konsentrasi gliserol akan menurunkan nilai kuat tarik dari film yang dihasilkan. Fenomena ini seiring dengan menurunnya kristalinitas bahan seperti telah diuraikan di atas. Menurut Sanyang et al. (2015), bentuk, jumlah atom karbon dalam rantai dan jumlah gugus hidroksil yang terdapat pada molekul gliserol akan mempengaruhi sifat mekanis (kekuatan tarik dan perpanjangan putus) suatu film. Penambahan gliserol akan mengurangi gaya antar molekul rantai polisakarida sehingga struktur film yang dibentuk menjadi lebih halus dan fleksibel. Dengan meningkatnya fleksibilitas maka kuat tarik dari film yang dibuat akan semakin kecil (Liu et al. 2013).

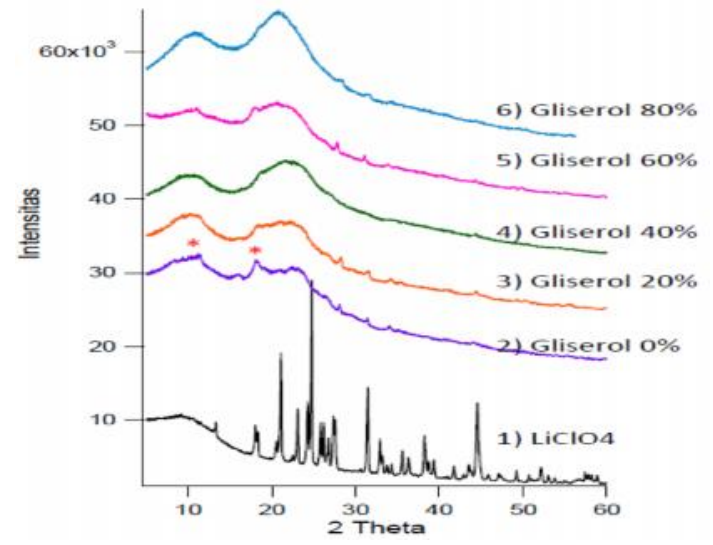

Gambar 1. Pola difraksi sinar X polimer komposit kitosan $\mathrm{ZrO}_{2}$ - $\mathrm{LiClO}_{4}$-Gliserol

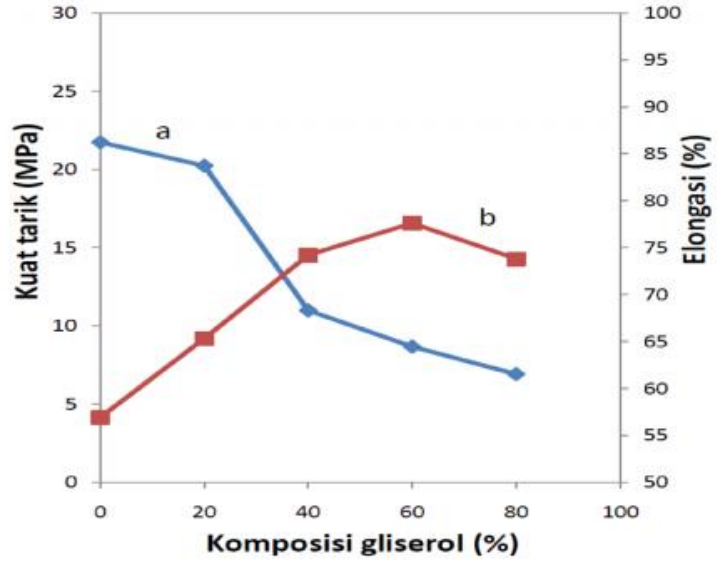

Gambar 2. Sifat mekanis komposit kitosan $\mathrm{ZrO}_{2}$ - $\mathrm{LiClO}_{4}$-Gliserol (a. Kurva kuat tarik, b.kurva elongasi) 
Pengukuran kuat tarik biasanya dilakukan bersamaan dengan pengukuran persentase perpanjangan (elongasi). Data hasil analisis pada Gambar 2 kurva (b). menunjukkan bahwa perpanjangan putus film meningkat dari $56 \%$ menjadi $78 \%$ dengan bertambahnya konsentrasi gliserol yang diberikan. Hal ini disebabkan oleh peningkatan jumlah gliserol akan menurunkan kekuatan gaya antar molekul sehingga mobilitas antar rantai molekul menurun dan presentasi pemanjangan film pun akan semakin meningkat. Gliserol dalam fungsinya sebagai plasticizer dapat menurunkan ikatan kohesi mekanik antara polimer dan dapat merubah sifat rigiditasnya sehingga film yang terbentuk lebih elastis. Penambahan gliserol akan mengurangi gaya intermolekuler sehingga mobilitas antar rantai molekul polimer meningkat. Hal ini yang menyebabkan film menjadi elastis dibandingkan tanpa penambahan gliserol (Sanyang et al. 2015). Penambahan gliserol mencapai optimal pada komposisi $60 \%$. Penambahan selanjutnya hingga $80 \%$ justru menurunkan elastisitas film komposit. Hal ini disebabkan karena penambahan gliserol sudah jenuh sehingga membentuk kluster yang mengurangi elastisitas polimer.

Spektroskopi impedansi merupakan salah satu metode yang tepat untuk melakukan karakterisasi sifat-sifat listrik dari bahan-bahan elektrolit dan interaksi antar muka bahan tersebut dengan elektroda penghantar. Dalam penelitian ini spektroskopi impedansi diukur sebagai fungsi frekuensi untuk melakukan analisis nilai konduktivitas ionik dan konstanta dielektrik sampel elektrolit polimer. Cole-Cole plot digunakan untuk memperoleh nilai konduktivitas ionik dari sampel kitosan- $\mathrm{ZrO}_{2}$ $\mathrm{LiClO}_{4}$ tanpa dan dengan gliserol $(20-80) \%(\mathrm{~b} / \mathrm{b})$ sebagai fungsi frekuensi seperti terlihat pada Gambar 3. Seperti terlihat pada Gambar 3, kurva terdiri dari daerah setengah lingkaran (depressed semicircle) pada frekuensi tinggi yang merepresentasikan kapasitor $(\mathrm{Cg})$ yang paralel dengan tahanan (resistor bulk $(\mathrm{Rb})$ dari bahan,dan loncatan (spike) yang terjadi pada frekuensi lebih rendah yang merepresentasikan constant phase element (CPE).

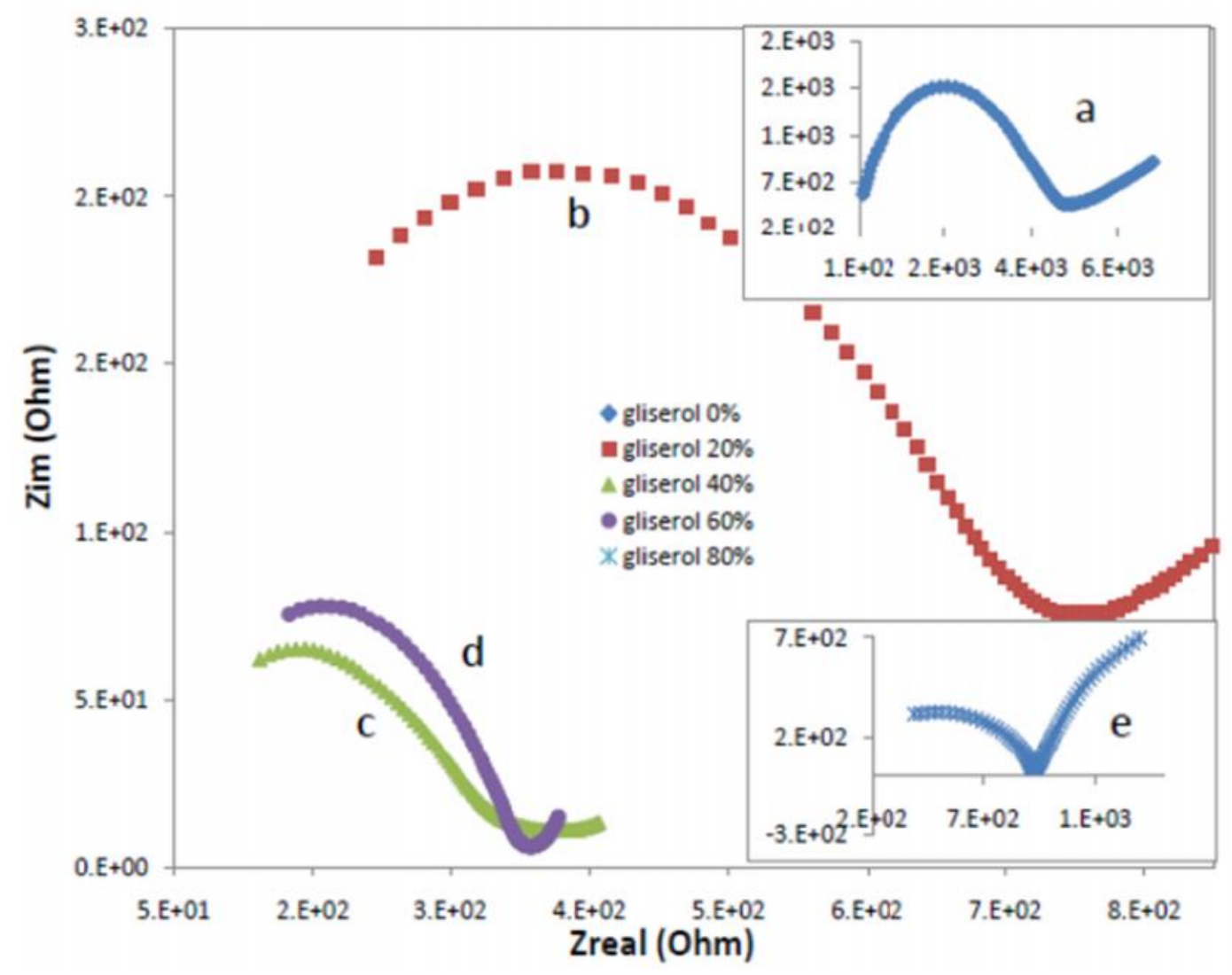

Gambar 3. Kurva impedansi komposit Kitosan- $\mathrm{ZrO}_{2}-\mathrm{LiClO}_{4}$-Gliserol (a. $0 \%$, b. $20 \%$, c. $40 \%$, d. $60 \%$ dan e. $80 \%$ ) 
Resistor merupakan gambaran migrasi ion yang terjadi di dalam volume bebas matriks polimer. Sedangkan kapasitor merepresentasikan rantai-rantai polimer tidak bergerak yang terpolarisasi pada arus AC. Peristiwa migrasi ion dan polarisasi terjadi secara parallel sehingga menghasilkan kurva berbentuk setengah lingkaran. Sedangkan garis miring lurus pada frekuensi rendah terjadi akibat efek antar muka antara elektroda dan elektrolit (Prabu et al. 2010; Subramanian and Pandi 2014).

Penambahan gliserol ke dalam sampel elektrolit polimer menyebabkan terjadinya penurunan nilai resistansi bulk $(\mathrm{Rb})$ (Gambar 3(b-d) dan daerah setengah lingkaran (semicircle) tetap terbentuk. Nilai Resistor bulk elektrolit polimer diperoleh dari intersep daerah setengah lingkaran dengan sumbu Zreal pada Cole-cole plot. Dengan program EIS Spectrum analyzer nilai $\mathrm{Rb}$ sampel elektrolit polimer dapat ditentukan. Konduktivitas ionik DC dapat dihitung menggunakan persamaan :

$$
\sigma=\frac{l}{R \cdot A}
$$

Dimana / adalah ketebalan sampel elektrolit polimer dan $A$ adalah luas daerah kontak antara elektrolit dan elektroda. Nilai konduktivitas tertinggi yang diperoleh adalah $3,52 \times 10^{-4} \mathrm{~S} / \mathrm{cm}$ dengan penambahan gliserol sebanyak $60 \%$ pada matrik polimer. Peningkatan konduktivitas ionik terjadi karena: 1) transisi fasa kompleks polimer dari fasa semikristalin menjadi amorf 2) kenaikan konsentrasi pembawa muatan 3) plasticizer dapat meningkatkan volume dalam sistem elektrolit dan menurunkan viskositas elektrolit sehingga mobilitas ion menjadi semakin mudah. Nilai konduktivitas elektrolit polimer untuk semua komposisi plasticizer dapat dilihat pada Tabel 1.

Konstanta dielektrik sebagai fungsi frekuensi mencerminkan respon dinamik dari komponen-komponen yang terkandung dalam material padat. Konstanta dielektrik atau permitivitas sampel elektrolit polimer dihitung dengan menggunakan persamaan :

$$
\varepsilon^{\prime}=\frac{Z^{\prime \prime}}{\omega C_{o}\left(Z^{\prime 2}+Z^{\prime 2}\right)}
$$

Dimana Z' dan Z" adalah impedansi real dan imajiner dari bahan, $\omega$ adalah frekuensi anguler dan $\mathrm{C}_{0}$ kapasitansi. Konstanta dielektrik ( $\left.\varepsilon^{\prime}\right)$ dihasilkan dari polarisasi total dari muatan yang terperangkap sebagaimana halnya dipol-dipol pada suatu material (Shukur et al. 2013). Konstanta dielektrik sampel elektrolit polimer komposit kitosan $\mathrm{ZrO}_{2}$ tanpa dan dengan plasticizer diperlihatkan pada Gambar 4.

Tabel 1. Perubahan konsentrasi plasticizer gliserol terhadap nilai konduktivitas elektrolit polimer kitosan$\mathrm{ZrO}_{2}-\mathrm{LiClO}_{4}$

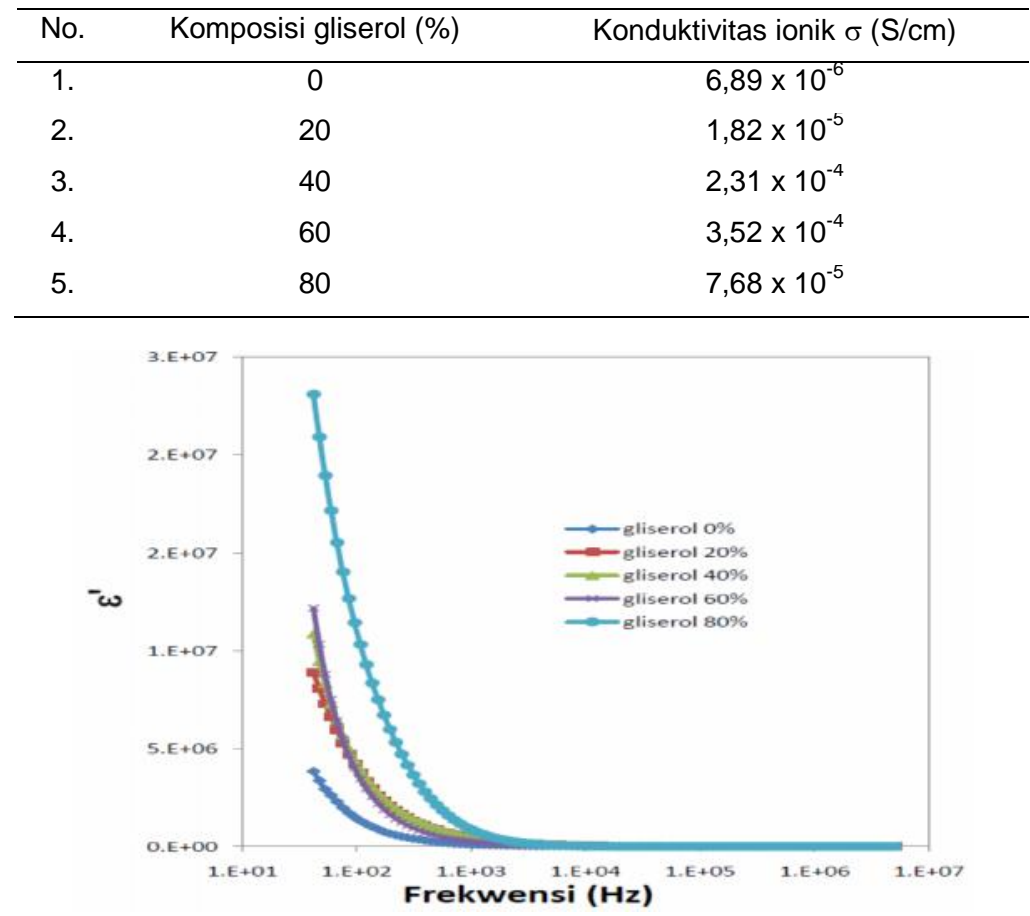

Gambar 4. Konstanta dielektrik elektrolit polimer Kitosan- $\mathrm{ZrO}_{2}-\mathrm{LiClO}_{4}$-gliserol 
Dari Gambar 4 terlihat bahwa nilai $\varepsilon$ ' untuk semua sampel terjadi pada frekuensi rendah. Pada daerah frekuensi rendah, nilai awal permitivitas dielektrik untuk material polar biasanya tinggi. Pada penelitian ini nilainya meningkat seiring meningkatnya konsentrasi plasticizer. Film elektrolit polimer tanpa plasticizer memiliki konstanta dielektrik $2,72 \times 10^{6}$, mengalami peningkatan menjadi $2,83 \times 10^{7}$ dengan penambahan plasticizer sebanyak $80 \%$ (b/b). Plasticizer merupakan bahan organik dengan konstanta dielektrik tinggi sehingga penambahan plasticizer mengakibatkan sampel elektrolit polimer semakin polar. Dispersi pada frekuensi rendah disebabkan oleh pengaruh muatan ruang yang mengakibatkan terjadi akumulasi pembawa muatan dekat elektroda. Sedangkan pada frekuensi tinggi terjadi pembalikan medan dengan periode tinggi di dekat antar muka (interface). Kontribusi pembawa muatan (ion) terhadap konstanta dielektrik akan menurun seiring kenaikan frekuensi. Pada frekuensi tinggi juga terjadi hamburan dipol-dipol sehingga tidak mampu mengikuti perubahan medan serta adanya efek polarisasi (Mohamed et al. 2014). Analisis jumlah transferensi ion dilakukan untuk pengukuran arus polarisasi dari ion-ion baik kation maupun anion dalam suatu bahan yang timbul akibat respon ion-ion terhadap beda potensial yang diberikan. Metode yang digunakan untuk mengukur jumlah transferensi ion ini adalah teknik polarisasi DC (Morni dan Arof 1999; Sudaryanto, Yulianti, dan Patimatuzzohrah 2016). Adapun hasil pengukuran nilai bilangan transferensi pada penelitian ini ditunjukkan pada Gambar 5.

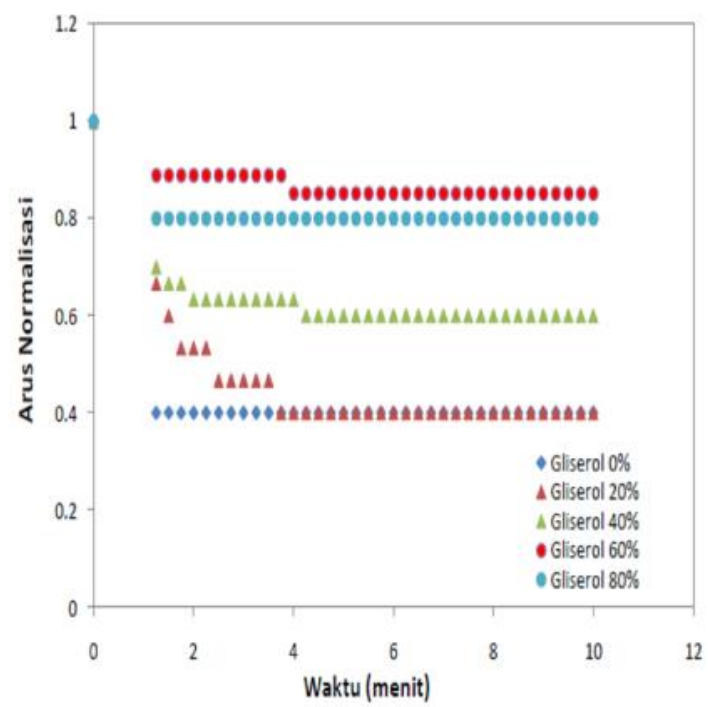

Gambar 5. Hasil Pengujian jumlah transferensi ion elektrolit polimer kitosan- $\mathrm{ZrO}_{2}-\mathrm{LiClO}_{4}$ gliserol
Gambar 5 menunjukkan bahwa semakin tinggi konsentrasi gliserol maka nilai bilangan transferensi meningkat. Penambahan gliserol meningkatkan derajat disosiasi garam, sehingga meningkatkan jumlah ion yang bergerak dalam matriks polimer. Nilai jumlah transferensi ion tertinggi didapatkan dari sampel dengan kandungan gliserol $60 \%$ dengan jumlah transferensi ion yang dihasilkan sampel tersebut adalah sebesar 0,85 yang berarti proses konduksi didominasi oleh kationik, yaitu ion $\mathrm{Li}^{+}$. Sedangkan konduksi anion yang ukurannya lebih besar terhalangi dengan semakin tinggi kandungan plasticizer. Selain itu struktur material juga merupakan faktor penentu dari kemudahan suatu ion untuk bergerak. Semakin amorf suatu material maka semakin mudah ionion bergerak dari satu rantai ke rantai polimer lain dalam suatu sistem elektrolit polimer padat. Hal ini didukung dengan hasil pengamatan menggunakan XRD dimana pada konsentrasi $60 \%$ gliserol diperoleh sampel dengan struktur amorf.

\section{KESIMPULAN}

Elektrolit polimer padat berbasis komposit kitosan- $\mathrm{ZrO}_{2}-\mathrm{LiClO}_{4}$ yang telah ditambah gliserol sebagai plasticizer telah berhasil dibuat dan dipelajari. Penambahan gliserol pada konsentrasi $60 \% \quad(\mathrm{~b} / \mathrm{b})$ telah meningkatkan konduktivitas ionik dari $6,89 \times 10^{-6}$ hingga $3,52 \times 10^{-4} \mathrm{~S} / \mathrm{cm}$. Penambahan gliserol mempengaruhi sifat intrinsik elektrolit polimer dengan film semakin amorf serta menjadi lebih elastis dan fleksibel. Penambahan gliserol juga meningkatkan jumlah transferensi ion dari 0,4 hingga 0,85 , sehingga memungkinkan untuk diaplikasikan pada sistem baterai.

\section{UCAPAN TERIMA KASIH}

Penulis mengucapkan terima kasih kepada Pusat Sains dan Teknologi Bahan Maju (PSTBM)-BATAN yang telah mendukung pelaksaan penelitian ini melalui pendanaan DIPA tahun 2015 dengan mata anggaran no. 4446.007.001.

\section{DAFTAR PUSTAKA}

Anitha, A., S. Sowmya, P. T Sudheesh Kumar, S. Deepthi, K. P. Chennazhi, H. Ehrlich, M. Tsurkan, dan R. Jayakumar. 2014. "Chitin and chitosan in selected biomedical applications." Progress in Polymer Science 39 (9). Elsevier Ltd: 1644-67. doi:10.1016/j.progpolymsci.2014.02.008.

Aziz, S. B., dan Z.H.Z. Abidin. 2014. "Iontransport study in nanocomposite solid polymer electrolytes based on chitosan: Electrical and dielectric analysis." Journal 
of Applied Polymer Science 41774: n/an/a. doi:10.1002/app.41774.

Buraidah, M H, L P Teo, S R Majid, dan A K Ã Arof. 2009. "Ionic conductivity by correlated barrier hopping in $\mathrm{NH} 4$ I doped chitosan solid electrolyte" 404: 1373-79. doi:10.1016/j.physb.2008.12.027.

Deraman, S. K., N. S. Mohamed, dan R. H Y Subban. 2013. "Conductivity and electrochemical studies on polymer electrolytes based on poly vinyl (chloride) - ammonium triflate-ionic liquid for proton battery." International Journal of Electrochemical Science 8 (1): 1459-68.

Fonseca, C.P., dan S. Neves. 2006. "Electrochemical properties of a biodegradable polymer electrolyte applied to a rechargeable lithium battery." Journal of Power Sources 159 (1 SPEC. ISS.): 712-16.

doi:10.1016/j.jpowsour.2005.10.095.

Harun, N.I., A.M. Ali, A.M.M. Ali, dan M.Z.A. Yahya. 2011. "Conductivity studies on cellulose acetate - ammonium tetrafluoroborate based polymer electrolytes" 15. doi:10.1179/143307511X1303189074885 8.

Kuo, C.W., W.B Li, P.R. Chen, J.W. Liao, C.G. Tseng, dan T.Y. Wu. 2013. "Effect of Plasticizer and Lithium Salt Concentration in PMMA- based Composite Polymer Electrolytes" 8: 5007-21.

Liu, H., R. Adhikari, Q. Guo, dan B. Adhikari. 2013. "Preparation and characterization of glycerol plasticized ( high-amylose ) starch - chitosan films." Journal of Food Engineering $116 \quad$ (2): 588-97. doi:10.1016/j.jfoodeng.2012.12.037.

Mohamed, S.A., A.A. Al-Ghamdi, G.D. Sharma, dan M.K. El Mansy. 2014. "Effect of ethylene carbonate as a plasticizer on Cul/PVA nanocomposite: Structure, optical and electrical properties." Journal of Advanced Research 5 (1). Cairo University: 79-86. doi:10.1016/j.jare.2012.11.008.

Morni, N.M., dan A.K. Arof. 1999. "Chitosanlithium triflate electrolyte in secondary lithium cells." Journal of Power Sources 77 (1): 42-48. doi:10.1016/S03787753(98)00170-0.

Navaratnam, S, K Ramesh, dan W J Basirun. 2011. "Investigation of ion conducting behaviour of composite chitosan based polymer electrolytes." Materials Research Innovations $15 \quad$ (1): 184-86. doi:10.1179/143307511X1303189074897 5.

Noor, M. M., M.A. Careem, S .R. Majid, dan A.K. Arof. 2011. "Characterisation of plasticised
PVDF-HFP polymer electrolytes." Materials Research Innovations 15 (s2): s157-60.

doi:10.1179/143307511X1303189074873 1.

Prabu, M., S. Selvasekarapandian, A.R. Kulkarni, G. Hirankumar, dan C. Sanjeeviraja. 2010. "Conductivity and dielectric studies on LiCeO2." Journal of Rare Earths 28 (3): 435-38. doi:10.1016/S1002-0721(09)60128-9.

Rahman, M. Y. A., A. Ahmad, T .K. Lee, Y. Farina, dan H .M. Dahlan. 2011. "Effect of Ethylene Carbonate (EC) Plasticizer on Poly (Vinyl Chloride)-Liquid 50\% Epoxidised Natural Rubber (LENR50) Based Polymer Electrolyte." Materials Sciences and Application 2 (July): 81826. doi:10.4236/msa.2011.27111.

Sanyang, M.L., S.M. Sapuan, M. Jawaid, M.R. Ishak, dan J. Sahari. 2015. "Effect of Plasticizer Type and Concentration on Tensile, Thermal and Barrier Properties of Biodegradable Films Based on Sugar Palm (Arenga pinnata) Starch," 1106-24. doi:10.3390/polym7061106.

Schnürch, A.B., dan S. Dünnhaupt. 2012. "Chitosan-based drug delivery systems." European Journal of Pharmaceutics and Biopharmaceutics 81 (3): 463-69. doi:10.1016/j.ejpb.2012.04.007.

Shukur, M. F., Y.M. Yusof, S.M.M. Zawawi, H.A. Illias, dan M.F.Z. Kadir. 2013. "Conductivity and transport studies of plasticized chitosan-based proton conducting biopolymer electrolytes." Physica Scripta T157: 14050. doi:10.1088/00318949/2013/T157/014050.

Stephan, A.M., dan K. S. Nahm. 2006. "Review on composite polymer electrolytes for lithium batteries." Polymer 47 (16): 595264. doi:10.1016/j.polymer.2006.05.069.

Subramanian, Selvasekarapandian, dan Vinoth Pandi. 2014. "Preparation and characterization of PVA complexed with amino acid, proline," no. July. doi:10.1007/s11581-014-1206-0.

Sudaryanto, E. Yulianti, dan Patimatuzzohrah. 2016. "Structure and properties of solid polymer electrolyte based on chitosan and ZrO2 nanoparticle for lithium ion battery." In AIP Conference Proceeding, 1710:020003-1. doi:10.1063/1.4941464.

Tripathi, S., G.K. Mehrotra, dan P .K. Dutta. 2008. "Chitosan based antimicrobial films for food packaging applications," no. 93: $1-7$.

Winie, Tan, N. S M Hanif, C. H. Chan, dan A. K. Arof. 2014. "Effect of the surface treatment of the $\mathrm{TiO} 2$ fillers on the 
properties of hexanoyl
chitosan/polystyrene composite polymer electrolytes." Ionics 20 (3): 347-52. doi:10.1007/s11581-0130983-1.

Yahya, M. Z. A., dan A .K. Arof. 2003. "Effect of oleic acid plasticizer on chitosan - lithium acetate solid polymer electrolytes" 39: 897-902. doi:10.1016/S00143057(02)00355-5.

Yulianti, E., J. Ginting, dan Sudaryanto. 2015. "Pengaruh Penambahan Garam Garam Litium Terhadap Sifat Elektrolit Padat polimer Berbasis Kitosan." Jurnal Sains Materi Indonesia 16: 133-38.

Yulianti, E., R.D. Saputri, S. Sudaryanto, H. Jodi, dan R. Salam. 2013. "Pembuatan Bahan Polimer Elektrolit Padat Berbasis Nanokomposit Kitosan Montmorillonite untuk Aplikasi Baterai." Jurnal Kimia dan Kemasan 35 (2): 77.

Yulianti, E, A Karo Karo, dan L Susita. 2012. "Synthesis of Electrolyte Polymer Based on Natural Polymer Chitosan by Ion Implantation Technique" 4: 202-7. doi:10.1016/j.proche.2012.06.028. 